\title{
LOKABASA
}

Jurnal Kajian Bahasa, Sastra, dan Budaya Daerah serta Pengajarannya

Volume 10, No. 1, April - 2019, Hal. 88-99

p-2338-6193 (print) | e-2528-5904 (online)

Homepage: http://ejournal.upi.edu/index.php/lokabasa doi: 10.17509/jlb.v10i1

\section{Tukuh Ciburuy: Sebuah Kajian Étnografi}

\author{
Rini Sri Indriani \\ Program Studi Pendidikan Guru Sekolah Dasar, Universitas Pakuan \\ rini_sriindriani@gmail.com
}

Sejarah Artikel: Diterima ( 25 November 2018); Diperbaiki (07 Januari 2019); Disetujui (20 Februari 2019); Pusblished (30 April 2019).

Bagaimana mengutip artikel ini (dalam gaya APA): Indriani, R.S. (2019). Tukuh Ciburuy: sebuah kajian étnografi. Lokabasa, 10(1), 1-11. doi: 10.17509/jlb.v10i1.16944

\begin{abstract}
Abstrak: Penelitian ini adalah sebuah penelitian etnografi untuk mengumpulkan data kebudayaan sebuah masyarakat etnik atau unik di Kabuyutan Ciburuy, Kabupaten Garut, Provinsi Jawa Barat. Analisis kualitatif dilaksanakan untuk memahami istilah tukuh Ciburuy sebagaimana diungkap oleh para ahli atau masyarakat di luar Kabuyutan Ciburuy. Sedangkan dokumentasi dan deskripsi digunakan untuk mengungkap berbagai adat, tali paranti, atau kebiasaan di Kabuyutan Ciburuy yang merepresentasikan sikap atau pandangan masyarakat Kabuyutan Ciburuy. Berdasarkan hasil penelitian, dapat diambil kesimpulan bahwa dalam tradisi Kabuyutan Ciburuy, tukuh Ciburuy bermakna teguh terhadap aturanaturan yang harus dilaksanakan secara rutin. Tukuh Ciburuy oleh masyarakat Kabuyutan Ciburuy dan Kampung Ciburuy diwujudkan dalam beberapa hal seperti pantangan dan upacara seba. Dalam tradisi Kabuyutan Ciburuy, pantangan diwujudkan dalam kegiatan-kegiatan atau hal-hal yang tidak boleh dilakukan oleh masyarakatnya. Pantangan-pantangan tersebut tidak boleh dilanggar. Jika dilanggar, dipercaya akan terjadi musibah terhadap orang yang melanggarnya. Upacara seba dilaksankan oleh masyarakat Ciburuy dengan berpegangan pada keyakinan bahwa upacara tradisi dianggap wajib dilaksanakan oleh masyarakat Kabuyutan Ciburuy. Hal tersebut diyakini dengan anggapan bahwa akan timbul hal-hal yang bersipat kuat dan magis. Jika dilaksankan, akan terhindar pula dari berbagai hal yang tidak diinginkan. Sebaliknya, jika tidak dilaksanakan akan menimbulkan akibat buruk bagi kehidupan sehari-hari masyarakat Ciburuy.
\end{abstract}

Kata Kunci: Tukuh Ciburuy; pantangan; upacara seba

\section{Tukuh Ciburuy: An Ethnographic Study}

Abstract: This research is an ethnographic study to collect cultural data from an ethnic or unique community in Kabuyutan Ciburuy, Kabupaten Garut, West Java Province. Qualitative analysis was carried out to understand Tukuh Ciburuy terminology as revealed by experts or communities outside of Kabuyutan Ciburuy. Whereas documentation and description were used to reveal various customs, taliparanti, or habits in Kabuyutan Ciburuy that represent the attitude or view of the people of Kabuyutan Ciburuy. Based on the results of the research, it can be concluded that in the Kabuyutan Ciburuy tradition, Tukuh Ciburuy means stick to the rules and implement it regularly. Tukuh Ciburuy manifested by Kabuyutan Ciburuy people and Ciburuy Village is in several ways such as in Pantangan and Seba ceremonies. In Kabuyutan Ciburuy tradition, Pantangan is manifested in activities or things that formally prohibit to be done by its society (taboo). These prohibitions have to be obeyed. If it is violated, it is believed that there will be a disaster for the person did it. The Seba ceremony is carried out by holding on the belief that the ceremony was considered an obligatory by the people of Kabuyutan Ciburuy. This belief is based on the assumption of wishful thinking that strong and magical phenomena will arise. If it is obeyed it will avoid the unwanted disaster. Conversely, if it is not fulfilled it will have a negative effect on Ciburuy people daily life..

Keywords: Tukuh Ciburuy; taboo; seba ceremony 


\section{PENDAHULUAN}

Dalam kehidupan masyarakat Sunda terdapat sebuah peribahasa yang berbunyi tukuh Ciburuy. Peribahasa tersebut biasanya untuk menunjukkan orang yang kukuh terhadap pendiriannya, walaupun sebenarnya tidak akan ada akibat jika orang tersebut merubah pendiriannya tersebut.

Kata Ciburuy yang terdapat dalam frase tersebut menunjukkan sebuah tempat yang sebenarnya lebih dari satu lokasi. Ketika dikaitkan dengan peribahasa tersebut, Ciburuy yang dimaksud adalah sebuah Kabuyutan (situs) di daerah Garut. Di tempat tersebut, terdapat komunitas adat yang kukuh memegang tali paranti, aturan hidup, dan kebiasaan.

Istilah Kabuyutan juga terliahat di beberapa prasasti dan naskah kuno, seperti dalam prasasti Kabantenan dan Naskah Amanat Galunggung. Disana dijelaskan bahwa Kabuyutan itu penting fungsinya untuk Raja. Kabuyutan juga dapat diartikan sebagai tempat suci, tempat bertapa para wiku atau pendeta, serta dianggap pusat kekuatan Raja dan kerajaannya. Tidak merasa aneh pada jaman itu kalau ingin menaklukan satu kerajaan itu yang pertama dimusnahkan oleh musuh Kabuyutannya. Kalau Raja berhasil melindungi Kabuyutan tersebut, maka suatu kehormatan unggulah bagi seorang raja itu. Sebaliknya, kalau seorang Raja tidak bisa melindungi Kabuyutan atau bisa direbut oleh musuh, maka martabat raja dianggap rusak dan harga dirinya disamakan dengan kulit lasun di tempat yang kotor (Wartini, 2007, hlm. 21-23).

Jadi intinya Kabuyutan mempunyai dua makna yaitu, merupakan hasil pekerjaan dan suatu temapat. Yang merupakan hasil pekerjaan yaitu mempunyai makna yang menyoko pada hasil para leluhur yang mengandung nilai moral atau ajaran-ajaran yang bermanfaat untuk kesempurnaan hidup. Sedangkan sebagai suatu tempat , Kabuyutan merupakan bangunan yang pernah digunakan untuk kegiatan keagamaan atau kegiatan ritual leluhur yang sudah menjadi resi, wiku aatau pandita (agamawan). Oleh sebab itu Kabuyutan dijadiakn tempat yang disakralkan, dikeramatkan dan dijadikan tempat yang tidak sembanranagan untuk dikunjungi.

Budaya erat kaitannya dengan tradisi. Tradisi bisa disebut juga adat istidat. Adat istiadat yaitu sistem budaya yang mencakup nilai-nilai budaya, pandangan hidup dan cita-cita, norma-norma dan hukum, pengetahuan, serta keyakinan yang diwariskan secara turun-temurun dari satu generasi kepada generasi berikutnya (Lubis, 2011, hlm. 273).

Yang menjadi pertanyaan kemudian adalah bagaimana sebenarnya bentuk dan sipat aturan atau kebiasaan tersebut. Jika merujuk pada keterangan Ajip Rosidi, Ciburuy adalah sebuah Kabuyutan, tentu saja kebiasaan tersebut berkaitan dengan tradisi yang terdapat di sebuah Kabuyutan. Kabuyutan adalah sebuah tempat yang dulunya merupakan lokasi pusat kegiatan keagamaan yang dipengaruhi oleh agama Hindu. Kabuyutan juga sering disebut mandala, tempat para pendeta memberikan pengajaran agama kepada murid-muridnya, mendoakan kesehatan dan keselamatan raja dan negara, dan tempat menuliskan aturan agama serta ilmu pengetahuan lainnya. Pengisi Kabuyutan atau mandala mendapatkan keistimewaaan tertentu, mendapatkan perlindungan khusus dan jaminan hidup dari rajanya, serta dibebaskan dari kewajiban membayar pajak (Rosidi, 2000, hlm. 315). 
Di Kabuyutan atau mandala juga dapat ditemui tradisi-tradisi yang dipegang teguh oleh pengisinya. Konsep tapa yang dimaksud adalah tapa di mandala dan tapa di nagara. Tapa di mandala yaitu menjalankan kewajiban di mandala, tujuannya menjaga tali paranti yang sudah diwariskan secara turun-temurun agar kesucian Kabuyutan dapat terjaga dengan baik. Sedangkan tapa di negara berkaitan dengan kegiatan tapa yang dilakukan oleh raja dalam rangka memenuhi kewajibannya untuk menjaga dan memakmurkan negara dan rakyatnya.

Penelitian ini dilaksanakan untuk mengetahui secara mendalam bagaimana sebenarnya tradisi atau adat istiadat yang terdapat dan dipegang teguh di lingkungan Kabuyutan Ciburuy. Peribahasa tukuh Ciburuy seperti yang diungkapkan di atas, bukan saja sebuah terminologi yang menggambarkan sikap dan perilaku manusia yang merujuk pada ketaatan memegang teguh sebuah tradisi, tapi bisa jadi lahir dari konsep kosmologi atau kehidupan budaya yang mencakup berbagai aspek. Tukuh Ciburuy, bisa jadi tidak hanya berkaitan dengan upacara-upacara tradisi dan kegiatan menjaga naskah kuno, tapi berkaitan juga dengan aturan adat lainnya yang dijaga oleh masyarakat Kabuyutan Ciburuy. Hal tersebut, selama ini belum banyak terungkap dalam berbagai penelitian.

\section{METODE}

Metode yang digunakan dalam penelitian ini adalah etnografi, berasal dari kata ethos yang bermakna bangsa atau suku bangsa, dan graphein yang bermakna tulisan atau ulasan. Etnografi merupakan sebuah penelitian mengenai kebudayaan sebuah masyarakat etnik atau unik, misalnya mengenai adat-istiadat, kebiasaan, religi, hukum, bahasa. Analisis kualitatif dilaksanakan untuk memahami istilah tukuh Ciburuy sebagaimana diungkap oleh para ahli atau masyarakat di luar Kabuyutan Ciburuy. Sedangkan dokumentasi dan deskripsi digunakan untuk mengungkap berbagai adat, tali paranti, atau kebiasaan di Kabuyutan Ciburuy yang merepresentasikan sikap atau pandangan masyarakat Kabuyutan Ciburuy yang taat adat dan kukuh dalam melestarikan warisan karuhun. Data yang diperlukan dikumpulkan menggunakan teknik observasi, wawancara, dan dokumentasi.

Lokasi penelitian yaitu Kampung Ciburuy, Desa Pamalayan, Kecamatan Bayongbong, Kabupaten Garut.

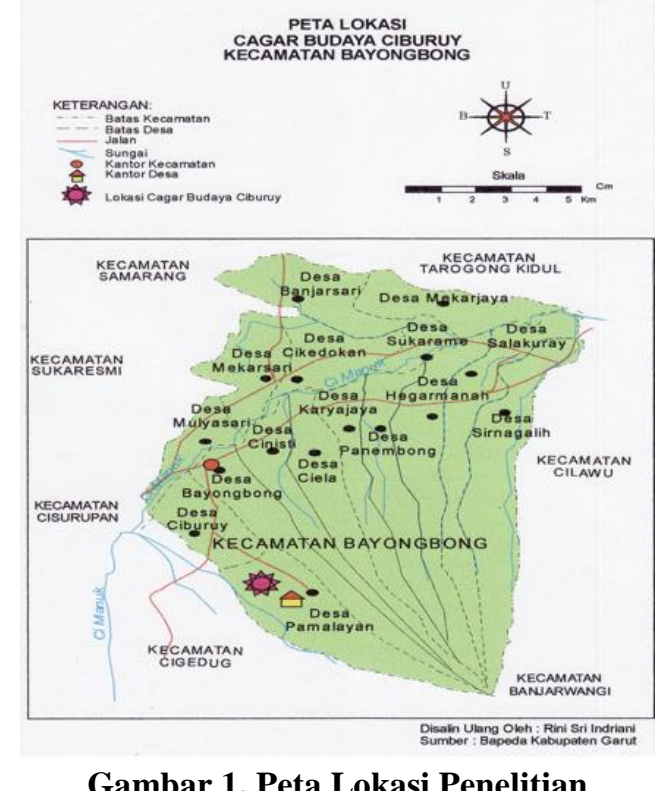

\section{HASIL DAN PEMBAHASAN}

Kabuyutan Ciburuy berada di Kampung Ciburuy, Desa Pamalayan, Kecamatan Bayongbong, Kabupaten Garut, Provinsi Jawa Barat. Jarak dari pusat kota Garut sekitar 20 kilometer. Lokasinya dibatasi oleh sungai Cisaat di sebelah timur, sungai Baranangsiang di sebelah Utara, Sungai Ciburuy di sebelah Barat, dan bukit 
di sebelah selatan. Bukit tersebut menjadi batas kampung Ciburuy dengan kampung Batugede. Kabuyutan Ciburuy berlokasi di bukit tersebut.

Masyarakat Ciburuy jumlahnya 1.726 jiwa, menempati 360 rumah. Pekerjaan masyarakat Ciburuy $50 \%$ sebagai petani (pemilik pertanian), $50 \%$ sebagai buruh tani. Pendidikan masyarakatnya rata-rata lulusan SD, jarang sekali yang melanjutkan ke jenjang pendidikan lebih tinggi.

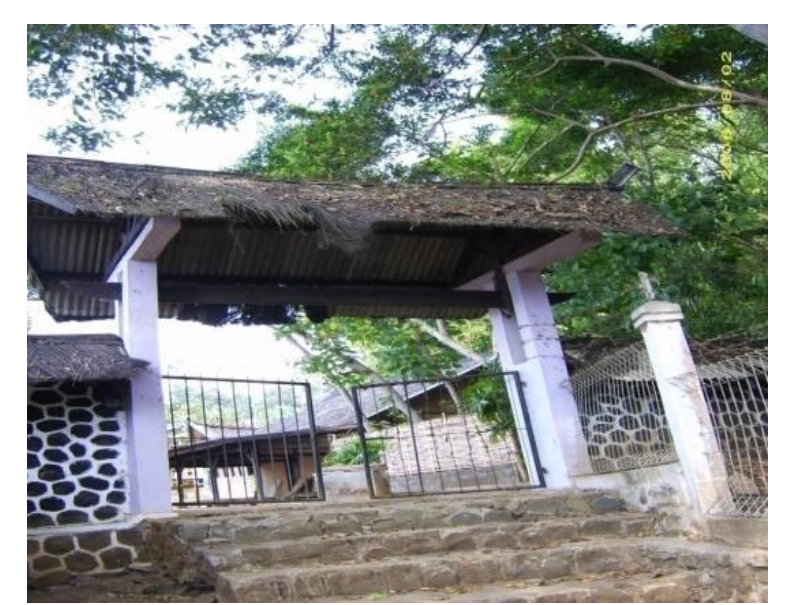

Gambar 2. Gerbang Masuk Kabuyutan Ciburuy

Berikut ini dipaparkan tentang pemertahanan aturan, adat istiadat, dan kebiasaan masyarakat Kabuyutan Ciburuy dalam Tukuh Ciburuy.

\section{Terminologi Tukuh Ciburuy}

Menurut Lembaga Bahasa dan Sastra Sunda Kamus Umum Basa Sunda (1995, hlm. 539) dan Satjadibrata (2005, hlm. 402) tukuh artinya kukuh atau kuat memegang pandangan hidup, tidak bisa diganggu gugat. Istilah tukuh Ciburuy merupakan sebuah peribahasa yang bermakna kukuh secara berlebihan, walaupun apa yang dipegang teguh tersebut bisa jadi ada yang salah dan tidak akan menimbulkan efek apapun ketika diubah atau ditinggalkan. Orang yang memegang teguh tukuh Ciburuy merupakan orang yang teguh dalam sikap dan pandangannya, tidak bisa digoda atau diiming-imingi oleh hal-hal lainnya demi keyakinannya tersebut.
Masyarakat Ciburuy merupakan keturunan karuhun Ciburuy yang pertama kali membangun kawasan Kabuyutan Ciburuy. Berdasarkan garis keturunan tersebut, masyarakat Ciburuy memiliki pandangan bahwa mereka harus mempertahankan Kabuyutan beserta aturan dan adat kebiasannya. Jika mereka tidak berlaku demikian, dipercaya akan terjadi musibah dalam bentuk penyakit dan kerugian hasil tani.

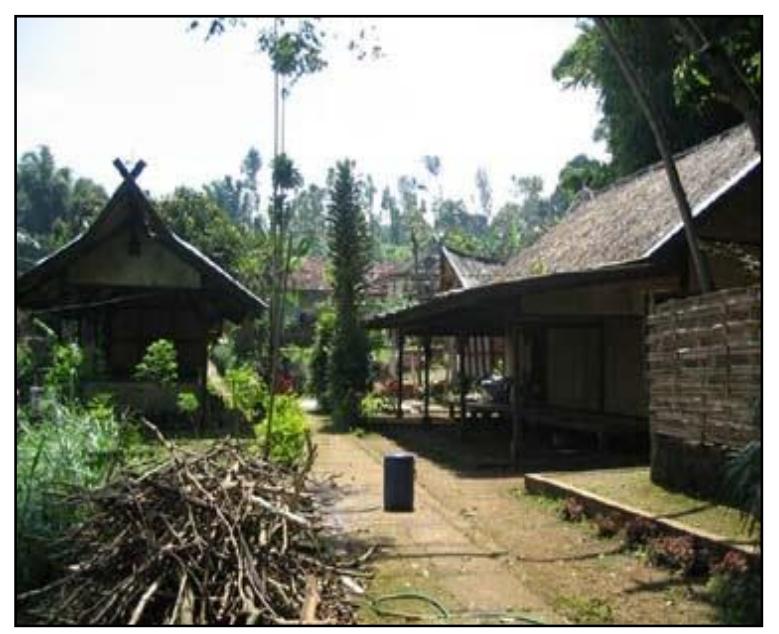

Gambar 3. Lokasi Kabuyutan Ciburuy

Dalam peribahasa masyarakat Sunda secara umum, dalam tradisi Kabuyutan Ciburuy, tukuh Ciburuy bermakna teguh terhadap aturan-aturan yang harus dilaksanakan secara rutin dalam bentuk pantangan dan upacara seba. Persamaan terminolognya terletak pada sikap teguh terhadap suatu hal, tidak bisa digoda demi keyakinannya tersebut.

Perbedaan terminologi Tukuh Ciburuy antara anggapan masyarakat Sunda secara umum dengan anggapan masyarakat Kabuyutan Ciburuy terutama terletak pada hal-hal sebagai berikut:

Tukuh Ciburuy yang dipegang teguh masyarakat Ciburuy lahir terlebih dahulu dari pada istilah sama yang lahir di masyarakat Sunda secara umum;

Tukuh Ciburuy yang dipegang teguh masyarakat Ciburuy terwujud dalam sikap teguh melaksanakan kegiatan-kegiatan tradisi warisan leluhurnya. Sedangkan dalam anggapan dan terminologi 
masyarakat Sunda secara umum, tidak dibatasi oleh kegiatan tradisi warisan leluhurnya saja, lebih luas kepada sikap dan pandangan hidup dalam berbagai hal.

\section{Tradisi dalam Tukuh Ciburuy Pantangan}

Dalam tradisi Kabuyutan Ciburuy, pantangan diwujudkan dalam kegiatankegiatan atau hal-hal yang tidak boleh dilakukan oleh masyarakatnya. Pantanganpantangan tersebut di antaranya sebagai berikut.

1. Tidak sembarangan orang bisa masuk ke dalam Kabuyutan Ciburuy. Jika hendak masuk, perlu ada izin khusus dari kuncen dengan tetap memperhatikan maksud dan keperluannya.

2. Tamu dari luar masyarakat Ciburuy, tidak diizinkan memasuki Kabuyutan Ciburuy pada hari Selasa dan Jum'at. Waktu-waktu tersebut khusus digunakan untuk kepentingan internal. Hari selasa adalah hari untuk bermusyawarah, sedangkan hari jum'at untuk kegiatan peribadahan.

3. Memasuki lingkungan dalam Kabuyutan Ciburuy, harus dalam keadaan suci, terutama untuk kalangan perempuan tidak boleh dalam keadaan sedang haid.

4. Membuka dan mengeluarkan barangbarang pusaka tidak bisa setiap waktu, hanya bisa pada waktu-waktu tertentu.

5. Makanan yang dibuat untuk keperluan upacara seba tidak boleh dimakan sebelum upacar seba selesai dilaksanakan.

6. Pantangan-pantangan tersebut tidak boleh dilanggar. Jika dilanggar, dipercaya akan terjadi musibah terhadap orang yang melanggarnya. Contohnya pernah terjadi ketika ada orang yang membuat makanan untuk upacara seba mencicipi makanan tersebut, mulut orang tersebut menjadi bengo.

\section{Upacara Seba}

Upacara tradisi dianggap wajib dilaksanakan oleh masyarakat Kabuyutan Ciburuy. Hal tersebut diyakini dengan anggapan bahwa akan timbul hal-hal yang bersipat kuat dan magis. Jika dilaksankan, akan terhindar pula dari berbagai hal yang tidak diinginkan. Untuk itulah upacara seba dilaksankan oleh masyarakat Ciburuy.

Upacara seba merupakan sebuah penghormatan masyarakat Ciburuy terhadap leluhurnya yang dianggap memiliki derajat adiluhung, yaitu arwah Prabu Kiansantang dan pengikutnya yang telah mewariskan keturunan dan bendabenda pusaka.

Sebagai sistem budaya, Esten (dalam Rekha, 2014, hlm. 10) menyebutkan bahwa tradisi merupakan suatu sistem yang utuh dengan mencakup cara memaknai ucapan, tingkah laku, ritual, dan tindakan lainnya dari satu manusia terhadap manusia lainnya. Unsur terkecil dari sistem itu adalah simbol. Simbol ini mencakup simbol konstitutitf (berbentuk kepercayaan), simbol kognitif (berbentuk ilmu pengetahuan), simbol yang berbentuk nilai moral, da simbol ekspresif atau simbol yang berhubungan dengan rasa. Setiap masyarakat memiliki simbol khusus yang membedakan dan sekaligus menjadi ciri identitas terhadap masyarakat lainnya. Jikalau suatu masyarakat sering berinteraksi dan hidup berdampingan dengan masyarakat lain yang heterogen, tentu besar kemungkinan suatu tradisi yang ada di masyarakat itu akan terpengaruh. Maka dari itu, dapat disebutkan bahwa tradisi merupakan bagian dari budaya.

Upacara seba diwujudkan dalam bentuk mengeluarkan benda-benda pusaka milik Kabuyutan Ciburuy. Dalam prosesnya, upacara seba hanya dilaksanakan satu tahun sekali, selama tiga hari berturut-turut pada bulan Mulud. 
Tabel 1. Waktu dan Urutan Upacara Séba

\begin{tabular}{cccl}
\hline Bulan & Hari ke- & Waktu & \multicolumn{1}{c}{ Kegiatan } \\
\hline Mulud & 1 & 07.00 & Membuat Kikis \\
& 2 & 15.00 & Membuat aneka makanan (ulén, wajit, ladu) \\
& 15.30 & Memasak dan menyiapkan aneka makanan \\
& 3 & 19.30 & Upacara Séba \\
\hline & \multicolumn{2}{c}{ Sumber: Hasil wawancara dengan Kuncén, tanggal 05 Januari 2011 }
\end{tabular}

Ada tiga hal penting dalam upacara seba, yaitu perkakas upacara, benda-benda pusaka, dan jenis makanan keperluan upacara. Perkakas berupa alat dan bahan upacara seba terdiri dari:

1) parukuyan;

2) bokor yang diisi air bunga tujuh jenis;

3) dua jenis air kopi, yang manis dan pahit;

4) sirih dan pendukungnya;

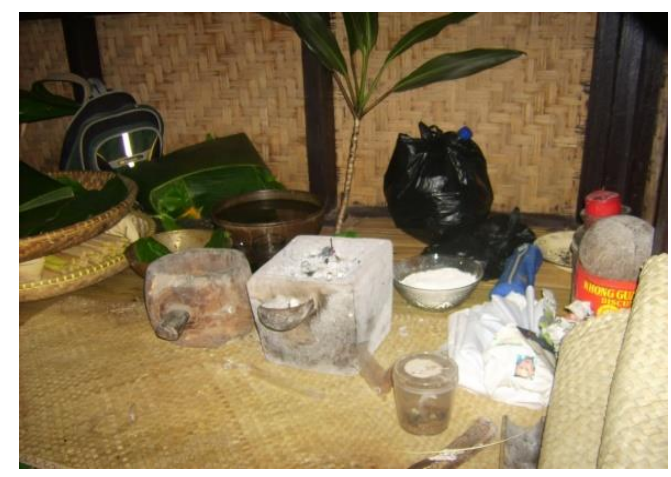

Gambar 4. Parukuyan
5) minyak keletik;

6) aneka makanan;

7) telur matang yang dimasukka ke dalam belahan buah kelapa, sisa belahan buah kelapa yang lainnya diposisikan menelungkup dekat parukuyan;

8) hanjuang hijau; dan

9) kampuh, untuk membungkus naskah.

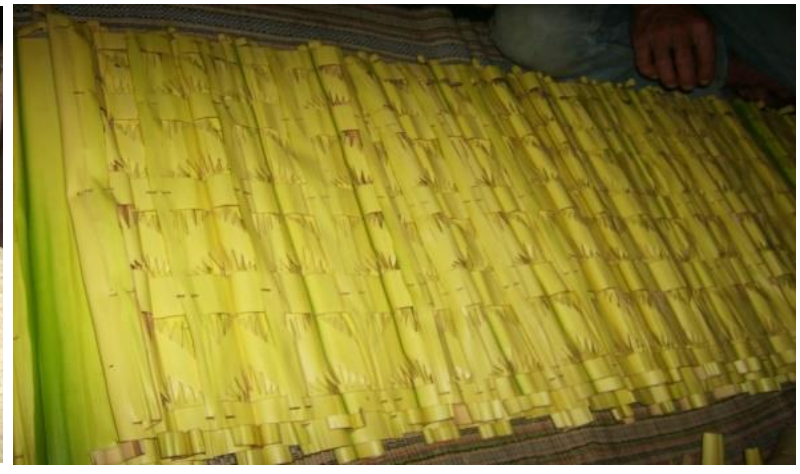

Gambar 5. Kampuh
Aneka jenis makanan yang disiapkan dalam upacara seba merupakan jenis-jenis makanan tertentu. Di antaranya ulen ketan, wajit, ladu, dan adeboy. Makanan tersebut berfungsi sebagai suguhan ketika upacara selesai dilaksanakan. Setiap orang yang hadir ketika upacara seba dapat memakan makanan tersebut.

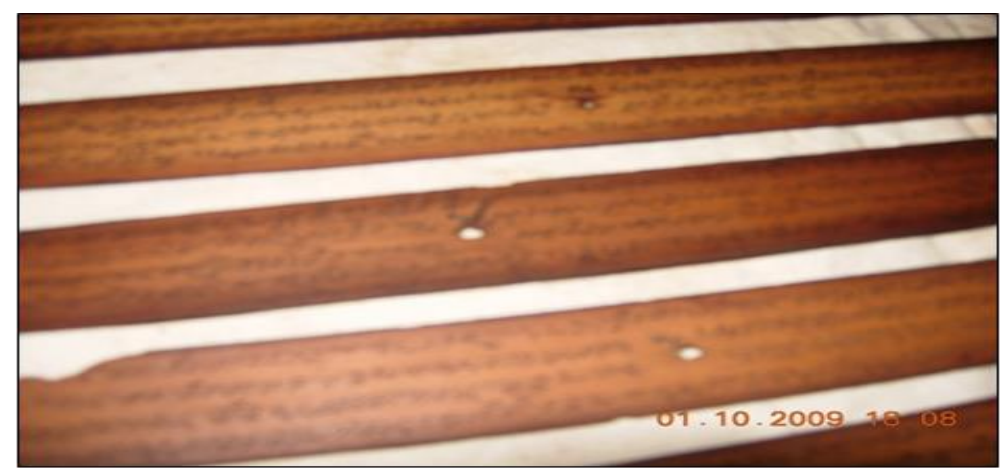

Gambar 6. Naskah Kabuyutan Ciburuy 
Berdasarkan hasil deskripsi Kuncen, naskah tersebut terbuat dari koropak triplek yang mempunya dimensi $32,3 \mathrm{~cm}$ X 5,2 cm $x$ 5,7 cm. Di bagian atasnya ada tulisan 18 , jadi disebutlah lontar koropak 18. Teks naskah lontar 18 tidak menyebutkan atau menunjukkan judul di luar teks atau pun di dalam teks. Meskipun begitu ditetapkan selaku bagian 9 fragmen) dari cerita Putra Rama dan Rawana atau yang lebih dikenal dengan pantun Ramayana. Sayang sekali isi ceritanya tidak lengkap, akibat hilangnya atau bercampur dengan lempir.

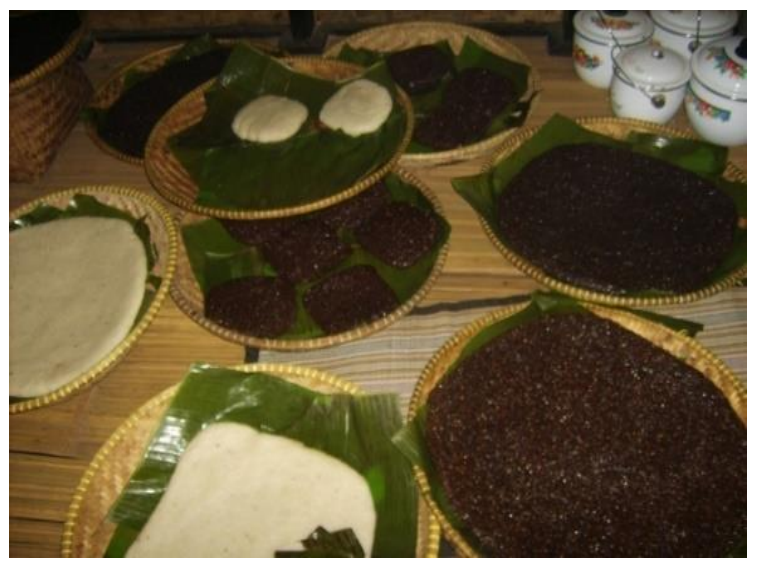

Gambar 7. Aneka Jenis Makanan

Barang-barang peninggalan purbakala yang terdapat di Kabuyutan Ciburuy yang merupakan bagian tidak terpisahkan dari upacara seba di antaranya:

1) naskah Kuno;

2) batu Pipih;

3) keris, Kujang, Trisula, Gunting, Tumbak;

4) kompleks Bangunan Adat, terdiri dari Padaleman, Patamon, Leuit, Pangalihan, Saung Lisung, dan Prasasti. Upacara seba dilaksanakan dengan beberapa tahapan. Tahapan-tahapan tersebut adalah sebagai berikut.

1) Persiapan, dilakukan oleh seluruh masyarakat yang terlibat dalam bentuk menyiapkan perkakas pendukung dan aneka jenis makanan.

2) Membersihkan dan menyiapkan lingkungan, yaitu kegiatan membersihkan lingkungan Kabuyutan Ciburuy dan bangunan-bangunan yang digunakan untuk upacara.
3) Upacara Seba, dimulai pukul 21.00 pada hari ketiga rangkaian upacara. Urutan kegiatannya terdiri dari pembukaan dan nyambat dan nyalikkeun oleh pimpinan upacara (kuncen) di padaleman, berpindah tempat ke patamon dengan membawa semua alat dan bahan upacara, membuka peti naskah dan perkakas, beberesih, dan ditutup dengan menyantap makanan yang telah disiapkan.

Beberesih dalam upacara seba merupakan kegiatan pokok. Dalam rangkaiannya, upacara beberesih yaitu membuka peti naskah kuno dan bendabenda pusaka. Naskah kuno dan bendabenda pusaka tersebut dibersihkan dari kotoran. Naskah kuno setelah dibersihkan dari debu, diganti pembungkusnya. Bendabenda pusaka berupa keris, kujang, trisula, gunting, dan tumbak dibersihkan menggunakan air tujuh jenis bunga dalam bokor. 


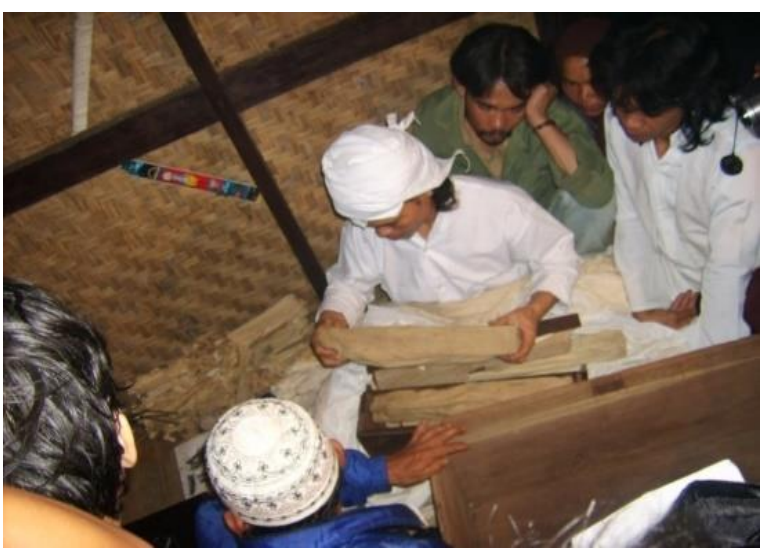

Gambar 8. Membuka dan membersihkan naskah kuno

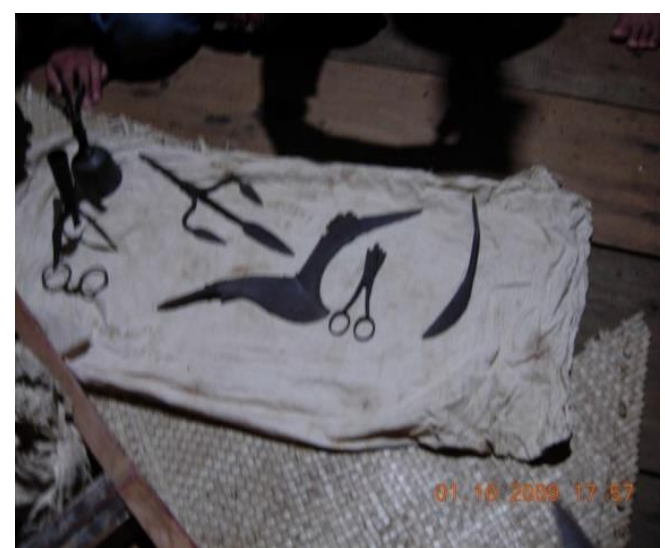

Gambar 9. Membuka dan membersihkan benda-benda pusaka

yang hadir mengalami kesurupan ketika prosesi nyalikkeun dilaksanakan. Hal tersebut menandakan roh leluhur telah hadir di tengah-tengah peserta upacara seba.

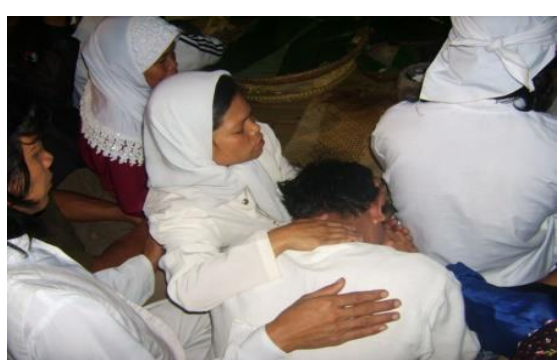

Gambar 10. Peserta upacara seba yang kesurupan

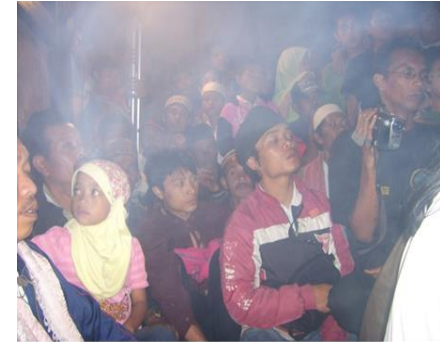

Gambar 11. Masyarakat yang menghadiri upacara Seba

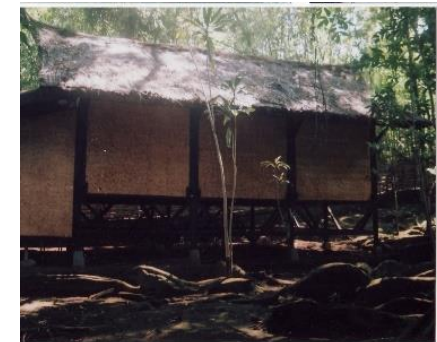

Gambar 12. Padaleman
Gambar di atas adalah padaleman, ukurannya menurut Kuncen 3 X 3 M, bangunan ini terbuat dari bambu dan atapnya dari ijuk serta alasnya dari papan atau kayu. Fungsi tempat ini untuk menyimpan barang-barang yang bersifat sakral, maksudnya tidak sembarangan orang harus melihat barang tersebut. Di dalam ruangan ini tersimpan barang pusaka dan Naskah. Orang yang ingin masuk dan melihat langsung barang pusaka tersebut, harus dengan sabar menunggu satu tahun lamanya dengan waktu yang sudah ditentukan.
Hasil penelitian, dalam tradisi Kabuyutan Ciburuy, tukuh Ciburuy bermakna teguh terhadap aturan-aturan yang harus dilaksanakan secara rutin dalam bentuk pantangan dan upacara seba. Persamaan terminolognya dengan peribahasa tukuh Ciburuy masyarakat Sunda secara umum terletak pada sikap teguh terhadap suatu hal, tidak bisa digoda demi keyakinannya tersebut.

Tukuh Ciburuy oleh masyarakat Kabuyutan Ciburuy dan Kampung Ciburuy diwujudkan dalam beberapa hal seperti pantangan dan upacara seba. Dalam tradisi Kabuyutan Ciburuy, pantangan 
diwujudkan dalam kegiatan-kegiatan atau hal-hal yang tidak boleh dilakukan oleh masyarakatnya. Pantangan-pantangan tersebut tidak boleh dilanggar. Jika dilanggar, dipercaya akan terjadi musibah terhadap orang yang melanggarnya, dan bisa dikatakan dengan istilah pamali.

Pamali merupakan larangan yang dibuat oleh nenek moyang yang diwariskan pada keturunannya. Setiap daerah memiliki pamali yang beragam yang berbeda dengan daerah lainnya, meskipun beberapa pamali mungkin ada yang sama. Sebagai mana yang dijelaskan Hidding (dalam Rahmat K, 2000, hlm. 15) bahwa pamali adalah larangan yang sifatnya tidak logis dan menakut-nakuti yang diwariskan secara turun-temurun dari generasi ke generasi seterusnya. Menakut-nakuti di sini mempunyai arti jika pamali itu dilanggar maka akan mendatangkan celaka atau kena batunya, petaka, sampai bisa mengakibatkan kematian yang dialaminya, baik si pelanggar maupun masyarakat sekitarnya. Pamali jika dilihat dari segi arti bukan hanya sekedar istilah yang diucapkan sembarangan, tapi dari pamali tersebut mengandung nilai pendidikan yang mengajarkan secara tidak langsung agar anak-anak menuruti petuah baik yang diucapkan oleh orang tuanya.

Pamali yang tersebar di masyarakat umumnya diklasifikasikan berdasarkan kepada siapa pamali tersebut ditujukan. Sebagaimana yang di jelaskan oleh Mustapa (2010, hlm. 14-19) bahwa pamali diklasifikasi kedalam lima kategori, seperti pamali untuk anak-anak, pamali untuk perawan dan perjaka, pamali untuk yang sedang mengandung, pamali untuk umum, dan pamali husus untuk satu kelompok saja.

Pamali tergolong kedalam kearifan lokal, sebab pamali dibuat dan dihasilkan dari pengetahuan satu kelompok masyarakat. Isnendes (2014, hlm. 195) menjelaskan bahwa kearifan lokal memiliki sifat abstrak sekaligus kongkret, pedomannya merupakan sistem abstrak, sedangkan dalam praktiknya merupakan sistem yang kongkret. Hal ini sejalan dengan aya dijelaskan oleh Alwasilah (2009, hlm. 51) bahwa kearifan lokal merupakan proses bagai mana pengetahuan dihasilkan, disimpan, diterapkan, diolah dan diwariskan. Kearifan lokal dijadikan pemebelajaran dalam kehidupan masyarakat, sebab memliki nilai-nilai pendidikan yang disampaikan secara tiadak langsung, seperti halnya dengan pamali.

Upacara seba dilaksanakan oleh masyarakat Ciburuy dengan berpegangan pada keyakinan bahwa upacara tradisi dianggap wajib dilaksanakn oleh masyarakat Kabuyutan Ciburuy. Hal tersebut diyakini dengan anggapan bahwa akan timbul hal-hal yang bersipat kuat dan magis. Jika dilaksanakan, akan terhindar pula dari berbagai hal yang tidak diinginkan. Sebaliknya, jika tidak dilaksanakan akan menimbulkan akibat buruk bagi kehidupan sehari-hari masyarakat Ciburuy.

Hal penting lainnya dari upacara seba adalah kegiatan beberesih dan nyalikkeun. Beberesih dalam upacara seba merupakan kegiatan poko. Dalam rangkaiannya, upacara beberesih yaitu membuka peti naskah kuno dan benda-benda pusaka. Naskah kuno dan benda-benda pusaka tersebut dibersihkan dari kotoran. Naskah kuno setelah dibersihkan dari debu, diganti pembungkusnya. Benda-benda pusaka berupa keris, kujang, trisula, gunting, dan tumbak dibersihkan menggunakan air tujuh jenis bunga dalam bokor. Sementara itu, kegiatan nyalikkeun adalah mengundang roh-roh leluhur untuk hadir di tengahtengah masyarakat yang melakukan upacara. Tak jarang, beberapa masyarakat 
yang hadir mengalami kesurupan ketika prosesi nyalikkeun dilaksanakan. Hal tersebut menandakan roh leluhur telah hadir di tengah-tengah peserta upacara seba.

Dalam kegiatan beberesih dan nyalikkeun, terdapat gambaran kosmologi yang menjadi dasar kepatuhan warga masyarakat Ciburuy kepada tradisi dan adat kebiasannya. Beberesih (membersihkan) mengandung makna membuang dan membersihkan kotoran, mewujudkan diri yang suci dan terhindar dari dosa agar mudah mendapatkan berkah. Gambaran kosmologi Gambaran kosmologi dari kegiatan tersebut menunjukkan konsep manusia sebagai mikrokosmos kehidupan yang seluruhnya harus menganut dan menjalankan ajaran dan aturan Sang Hyang Darma. Dengan begitu, manusia akan menjadi makhluk ideal yang nantinya akan mencapai kesempurnanaan abadi. Ada kalanya manusia melenceng dari aturan, maka harus membersihkan diri agar mampu kembali suci dan bersih.

Kegiatan nyalikkeun merupakan gambaran usaha mendapatkan petuah dan hidayah ilahiyah, untuk mencari solusi dari berbagai persoalan yang dihadapi. Hal tersebut juga menggambarkan usaha mencapai keutamaan hidup manusia yang religius-holistik dalam kehidupan nyata. Hal tersebut menghasilkan makrokosmos, menghadirkan yang kudus ke yang nyata, menampakkan hal yang keramat ke alam manusia. Tujuan luasnya, menebarkan berkah ke seluruh ruang dan membersihkan wilayah ruang profane. Melalui nyalikkeun, mandala diciptakan, dan esensi dihadirkan ke alam ruang manusia. Orang yang kesurupan dianggap sebagai mediator yang menghubungkan dunia atas (buana nyungcung) dengan dunia manusia (buana pancatenga).

\section{SIMPULAN}

Berdasarkan analisis yang berkaitan dengan terminologi tukuh Ciburuy serta tradisi yang dipegang teguh oleh masyarakat Ciburuy dapat disimpulkan seperti ini. Dalam tradisi Kabuyutan Ciburuy, tukuh Ciburuy yaitu teguh trhadap aturan-aturan yang harus dilaksanakan secara rutin dalam wujud pantangan dan upacara seba. Salah satu tukuh yang utama yang sering dilaksanakan yaitu membersihkan barang-barang pusaka yang berada di tempat itu. Serta harus diadakannya jenis makanan untuk kegiatan upacara seba yaitu Ladu yang tidak dicampur tepung. Ulen asli dari beras ketan, lalu wajit yang tidak dibungkus. Bahanbahan tersebut asli dari hasil pertanaian masyarakat Ciburuy. Tradisi Sunda secara umum, istilah tukuh Ciburuy dipakai dan digunakan oleh masyarakat Sunda yaitu dalam bentuk peribahasa. Peribahasa tukuh ciburuy artinya teguh secara berlebihan, meskipun sebenarnya itu semua semu atau tidak semuanya benar atau tidak ada akibatnya seumpama dirobah. Tukuh ciburuy mengandung arti bahwa manusia itu harus teguh pada sikap dan pendirian. Tidak bisa digoda atau diiming-iming dengan hal yang lain demi keyakinan yang dipegangnya.

Terminologi tukuh Ciburuy yang berkembang dari peribahasa di masyarakat secara umum, meskipun maknanya ada yang serupa, ternyata berbeda dengan terminologi yang dipegang teguh oleh masyarakat Ciburuy. Persamaan terminologi tukuh Ciburuy yang dipegang teguh oleh masyarakat Ciburuy dan dalam peribahasa sunda yaitu sikep yang benar- 
benar teguh tidak dapat tergoda dan diiming-iming oleh apapun demi keyakinan yang dipegangnya. Sedangkan perbedaanya adalah tukuh Ciburuy yang dipegang teguh oleh masyarakat Ciburuy ternyata telah duluan lahir daripada peribahasa masyarakat Sunda. Tukuh Ciburuy yang dipegang teguh oleh masyarakat Ciburuy berwujud pada sikap keteguhan melaksanakan kegiatan-kegiatan yang ada dalam tradisi leluhur, sedangkan dalam peribahasa tidak dibatasi oleh tradisi, tapi merupakan sikap yang teguh pada halhal yang dianggap suatu keyakinan.

Tukuh Ciburuy dalam masyarakat Ciburuy berwujud dalam bentuk laranagn dan upacara seba. Dalam tradisi Kabuyutan Ciburuy, larangan yang berwujud dalam kegiatan-kegiatan atau hal-hal yang bisa dilakukan oleh masyarakatnya. Masyarakat Ciburuy begitu teguhnya terhadap larangan tersebut, seumpama dilanggar akan mengakibatkan musibah terhadap orang yang melanggarnya.

Larangan yang ada di Kabuyutan Ciburuy adalah tidak sembarangan orang lain masuk ka wilayah Kabuyutan Ciburuy. Untuk bisa masuk ke tempat tersebut harus ada ijin dari Kuncen dan harus jelas keperluannya untuk apa. Untuk pendatang atau tamu bagian internal Kabuyutan Ciburuy tidak boleh masuk pada hari selasa dan jumat. Kalau dilihat dari cerita atau dongeng, hari tersebut dipakai untuk kegiatan -kegiatan internal. Hari selasa dipakai untuk musyawarah sedangkan hari jumat dipakai untuk kegiatan ibadah. Orang lain yang datang ke Kabuyutan Ciburuy harus dalam keadaan suci, terutama wanita kalau sedang ada halangan jangan sengaja mendatangi tempat itu. Membuka dan mengeluarkan barang-barang pusaka tidak sembaranagn, tapi sudah ada waktu yang tepat. Makanan yang diolah untuk keperluan upacara seba tidak bisa dimakan atau dicoba terlebih dahulu sebelum upacara selesai.

Upacara seba merupakan kegiatan wajib yang secara rutin harus dilaksanakan setiap tahun oleh masyarakat Ciburuy yang percaya terhadap hal tersebut. Sebelum upacara dilaksanakan suka diadakan dulu tawasulan atau waktu nyepi, maksudnya untuk meminta ijin, meminta maaf, biasanya melaksanakan wirid atau bertasbih, dilaksanakan pada malam selasa dan malam rabu. Hari senin dari pagi masyarakat Ciburuy membuat kikis yang terbuat dari bambu. Hari selasa khusus untuk membuat aneka makanan.

Sebelum melaksanakan upacara seba melakukan beberesih di sekitar Kabuyutan, upacara seba dilaksanakan pada hari Rabu minggu ke tiga bulan Muharam dari jam sembilan malam sampai tengah malam, penutup yaitu kegiatan membersihkan barabg pusaka yang terbuat dari kuningan, seterusnya mempersilahkan makan pada masyarakat yang turut menyaksikan upacara seba. Orang-orang yang mengikuti upacara tersebut harus benar-benar percaya dan yakin bahwa nenek moyangnya menyimapan barang-barang bersejarah di tempat itu.

Tanda indeks dalam tradisi Tukuh Ciburuy di Kabuyutan Ciburuy Kecamatan Bayongbong Kabupaten Garut terlihat dalam kegiatan beberesih dan nyalikkeun. Tanda indeks dalam kegiatan beberesih mempunyai makna selaku mensucikan diri supaya tidak terkena dosa dan supaya diberi keberkahan dalam menjalani kehidupan. Gambaran kosmologi dari kegiatan tersebut ada dalam konsep manusia yang berwujud bentuk mikrokosmos alam kehidupan yang seutuhnya harut dianut serta menjalankan aturan Sang Hyang Darma atau Sanghiyang Darma. Nantinya akan menjadi makhluk yang ideal dan 
mendapat kesempurnaan hidup. Kegiatan nyalikkeun yaitu mengundang ruh leluhur supaya bisa merasuk ke salah seorang yang dianggap mampuh atau kuat untuk menyerupainya. Mantra-mantra dan amanat yang diucapkan sebagai ramalan kehidupan yang akan datang supaya dilaksanakan sebagai reaksi terhadap kejadian yang menimpa jaman sekarang. Tanda indeks nyalikkeun merupakan usaha meraih tujuan untuk memdapatkan petunjuk atau hidayah yang ilahiah, untuk mencari solusi dari persoalan yang dihadapi serta meraih keutamaan hidup manusia yang religius-holistik dalam kehidupan nyata.

Sesajen yang ada didalam upacara sebagai tanda simbol atas menyatunya kosmos. Dunia atas dan dunia manusia, maksudnya hal tersebut merupakan syarat tercapainya keselamatan, sejahetra dan kesuburan untuk kehidupan manusia. Dari awal kehidupan perantasa azas wanita dan azas lelaki sampai ke kehidupan setelah didunia atas.

Tanda simbol dalam tradisi tukuh Ciburuy berdasarkan referent yang bisa dimaknai selaku adanya keyakinan masyarakat Sunda buhun di Kabuyutan Ciburuy terhadap kosmologi Sunda buhun.

\section{UCAPAN TERIMA KASIH}

Penulis mengucapkan terima kasih kepada tim penyunting jurnal Lokabasa atas dipublikasikannya penelitian ini.

\section{CATATAN PENULIS}

Penulis menyatakan bahwa tidak ada konflik kepentingan terkait publikasi artikel ini. Penulis mengkonfirmasi bahwa data dan artikel ini bebas plagiarisme.

\section{PUSTAKA RUJUKAN}

Alwasilah, A. C. (2009). Pokoknya Kualitatif: Dasar-dasar Merancang dan Melakukan Penelitian Kualitatif. Jakarta: Pustaka Jaya.

Isnéndés, R. (2014). "Estetika Sunda Sebagai Bentuk Kearifan Lokal Masyarakat Sunda Tradisional dalam Sawangan Pendidikan Karakter". Jurnal Pendidikan dan Pengajaran, 1 (2).

Lembaga Basa Jeung Sastra Sunda. (1995). Kamus Umum Basa Sunda. Bandung: Tarate Bandung.

Lubis, N.H. dkk. (2011). Sejarah Kebudayaan Sunda. Bandung: Yayasan Masarakat Sejarawan Indonesia

Mustapa, H. (2010). Adat Istiadat Sunda. Bandung: Alumni.

Rahmat K. O. (2000). Materi Dasar Ilmu Budaya Sunda. Bandung: Universitas Pasundan.

Rekha, R.D. (2014). Tradisi Babarit Désa di Kecamatan Palasah Kabupatén Majaléngka (Ulikan StrukturalSémiotik). Tesis, Sekolah Pasca Sarjana Universitas Pendidikan Indonesia, Bandung

Rosidi, A. spk. (2000). Énsiklopedi Sunda. Jakarta: Pustaka Jaya.

Satjadibrata, R. (2005). Kamus Basa Sunda. Bandung: Kiblat Buku Utama.

Wartini, T. (2007, Mei). Kabuyutan Ciburuy. Cupu Manik [Majalah], 2123.: Bandung. 